\title{
The state of six dangerous glacial lakes in the Nepalese Himalaya
}

\author{
Nitesh Khadka ${ }^{1,2}$, Guoqing Zhang ${ }^{1,3, *}$, and Wenfeng Chen ${ }^{1}$ \\ ${ }^{1}$ Institute of Tibetan Plateau Research, Chinese Academy of Sciences, Beijing, China \\ ${ }^{2}$ University of Chinese Academy of Sciences, Beijing, China \\ ${ }^{3}$ CAS Center for Excellence in Tibetan Plateau Earth Sciences, CAS, Beijing, China
}

\begin{abstract}
Article history:
Received 18 February 2018

Revised 19 July 2018

Accepted 28 September 2018

Keywords:

Potentially dangerous glacial lakes, Glacier lake outburst floods (GLOFs), Risk assessment, Nepalese Himalaya

Citation:

Khadka, N., G. Zhang, and W. Chen, 2019: The state of six dangerous glacial lakes in the Nepalese Himalaya. Terr. Atmos. Ocean. Sci., 30, 63-72, doi: 10.3319/TAO.2018.09.28.03
\end{abstract}

\begin{abstract}
Glaciers in the Himalaya are increasingly retreating and thinning due to climate change. This process is the primary cause of glacial lakes expansion and has increased the possibilities of the glacial lake outburst floods (GLOFs) that have been responsible for heavy loss of life and damage to downstream infrastructures. This study examines the status of the existing potentially dangerous glacial lakes in the Nepalese Himalaya such as Imja Tsho, Tsho Rolpa, Thulagi, Chamlang South, Barun Tsho, and Lumding Tsho; which were more susceptible to GLOF after the devastating earthquake in 2015. We examined the evolution and decadal expansion rate of lakes from 1987 to 2016 using Landsat images. The results show significant expansion of Imja Tsho, Barun Tsho, and Lumding Tsho at the rates of 42.1, 46.8, and 32.9\% respectively, during 2006 - 2016; while other glacial lakes (i.e., Chamlang South, Barun Tsho, and Lumding Tsho) are relatively stable. Although the current status of glacial lakes may be stable in term of burst risk, high expanding lakes must be prioritized for detail studies. Continuous model-based monitoring and risk assessment, mitigation measures and disaster management strategies are necessary for reducing the impact of GLOFs.
\end{abstract}

\section{INTRODUCTION}

The total glaciated area of Himalaya is $22990 \mathrm{~km}^{2}$ (Bolch et al. 2012) and there are more than 4000 glacial lakes in the Himalaya (Zhang et al. 2015; Nie et al. 2017). Almost $800 \mathrm{~km}$ of the Himalayan range runs through Nepal (Le Fort 1975). Previous studies have found that the Himalayan glacial lakes display a complex episodic patterns of change (Nie et al. 2017). The glacial lakes in the Himalaya are different from the glacier-fed large lakes found in Tibet, especially in the inner basin. The glacial lakes in Himalayas are usually connected with glacier terminus and have small area (Zhang et al. 2015), however glacier-fed lakes in Tibet have melting water supply within the basin, are far from glacier and are large in size (Zhang et al. 2017a).

Glacial lake studies in the Nepalese Himalaya are very important because these lakes are good indicators of the significant change of climate that has occured. Since the early 1970s there has been notable warming in the Nepalese Himalaya (Shrestha et al. 1999); and since the early 1960s

\footnotetext{
* Corresponding author

E-mail:guoqing.zhang@itpcas.ac.cn
}

new glacial lakes have been appearing and increasing in size (Mool et al. 2001; Bolch et al. 2008). This trend still continues (Zhang et al. 2015; Nie et al. 2017). This increase in the number and size of glacial lakes adds to the risk of glacial lake outburst flood (GLOFs) events (Ives et al. 2010; Shrestha and Aryal 2011). The recent inventory has found $1541\left(80.95 \pm 15.25 \mathrm{~km}^{2}\right)$ glacial lakes in 2017 across the Nepalese Himalaya (Khadka et al. 2018). ICIMOD has listed 21 potentially dangerous glacial lakes (PDGL) identified by combination of remote sensing techniques and extensive field study. Out of 21 PDGL, 6 glacial lakes (Imja Tsho, Tsho Rolpa, Thulagi, Chamlang South, Lumding Tsho, and Lower Barun Tsho; Tsho is local language for lake) are ranked as highly critical undergoing studies of expansion rate, glacier and dam conditions, and topographic characteristics, in addition surveying the possible socio-economic damage from their probable burst (ICIMOD 2011). The GLOFs that have already occurred from different glacial lakes in Nepal along with transboundary GLOFs were very destructive, causing of loss of life and property and heavy economic loss; damaging hydropower installations, roads, and other infrastructures (Richardson and Reynolds 2000; Lutz et al. 2016). 
A systematic and scientific investigation is needed to provide a better understanding of current knowledge and wider dissemination of research advances on dangerous glacial lakes in the Nepalese Himalaya. Some individual glacial lakes of the Nepalese Himalaya, like Imja Tsho have been examined extensively. Aftermath of the devastating earthquake in 2015, Department of Hydrology and Meteorology, Nepal (DHM) had warned the existing six PDGL mentioned above at a high risk of bursting (Acharya 2016) as their field investigation identified cracks on outlet channel of Tsho Rolpa (Byers III et al. 2017). Majority of aftershocks of earthquake occurred north-east of Kathmandu (Goda et al. 2015), where the dangerous glacial lakes are located. A field-based study concluded that earthquake contributed for further destabilizing the existing conditions of glacial lakes through the creation of new cracks in the terminal moraines, shifted boulders, loss of land through landslides, and outlet channel slumping (Byers III et al. 2017). This paper has systematically reviewed the status of the six glacial lakes in the Nepalese Himalaya mentioned above.

\section{METHODOLOGY}

\subsection{Study Area}

Nepal is located in the central Himalaya, and is surrounded by China to the north and India to the south, east, and west. Nepal has a total land area of $147181 \mathrm{~km}^{2}$ and a population of 26.4 million (CBS 2012). Nepal can be di- vided into three physiographic regions, i.e., Himalaya, Hill, and Terai (plains). More than $80 \%$ of the country is mountainous (Shrestha and Zinck 2001). The river basins of Nepal are transboundary being shared with Tibet-China and India. The Koshi basin in the eastern region, Gandaki basin in the central region and Karnali basin in the western region are the main river basins of Nepal. The climate of the Nepalese Himalaya is dominated by the Indian monsoon with most of the precipitation occurring in summer during June - September (Ueno et al. 2001). There are numerous glacial lakes located at high altitude in the northern part of Nepal, which are susceptible to GLOFs. This study is focused on six PDGL identified by International Centre for Integrated Mountain Development (ICIMOD) as shown in Fig. 1.

\subsection{Methods Used}

The data used are based on Landsat data, published scientific papers, and various reports and other related documents. The latter have been obtained from a variety of sources such as web sites, and academic and research institutions. A total of 8 ortho-rectified Level 1 with cloud-free Landsat TM/OLI images of $30 \mathrm{~m}$ resolution of the day time for the month of October or November were downloaded from the web portal (https://earthexplorer.usgs.gov/). This images were used to map lake extents in 1987, 1996, 2006, and 2016. Normalized Difference Water Index (NDWI) developed by McFeeters (1996) is widely used for delineation

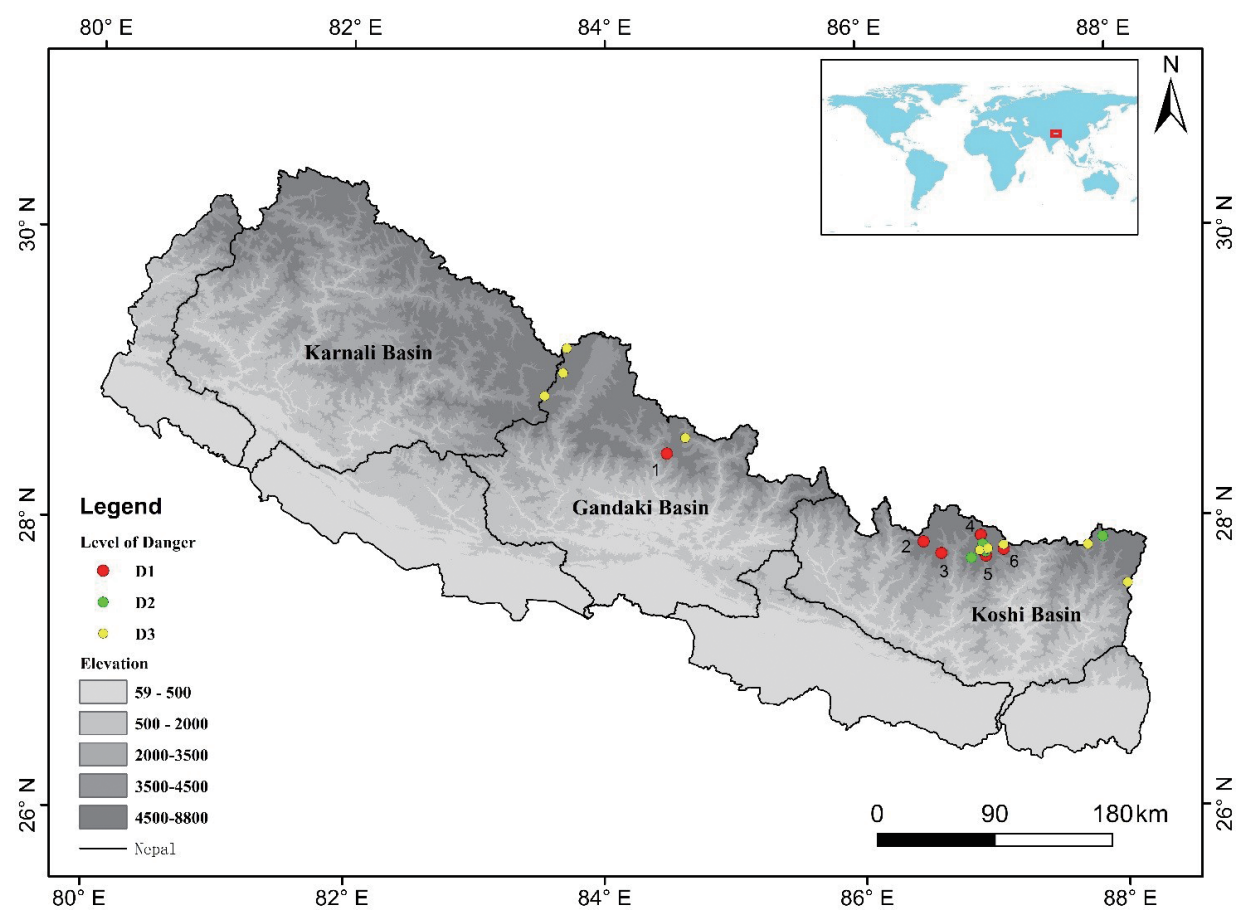

Fig. 1. The inset shows the location of Nepal. Potential dangerous glacial lakes in Nepal (ICIMOD 2011). D1, D2, and D3 indicate danger/critical priority with D1 the highest priority that requires monitoring, extensive field investigation and mapping. Here, $1=$ Thulagi (Dona); $2=$ Tsho Rolpa; 3 = Lumding Tsho; 4 = Imja Tsho; 5 = Chamlang South Tsho; 6 = Barun Tsho (Lower). 
of water bodies (lakes) from remotely sensed digital imagery [Eq. (1)]. An algorithm developed by Zhang et al. (2017b) was used to delineate the boundaries of glacial lakes using Landsat images, which determines the optimal threshold of normalized difference water index (NDWI) images by Otsu method. The delineated glacial lake boundary was visually checked and edited. The analysis tools used for the study were Microsoft Excel and ArcGIS 10.4.1. The supplementary datasets provided with some scientific articles were also downloaded and used for interpretation and evaluation of glacial lakes. The overall status of glacial lakes, their evolutions, expansion and the consequences of their changes were evaluated and conducted.

$\mathrm{NDWI}=\frac{\rho \text { Green }-\rho \text { NIR }}{\rho \text { Green }+\rho \text { NIR }}$

where, $\rho$ Green and $\rho$ NIR are top-of-the-atmosphere reflectance for the green and near-infrared bands.

\subsection{A Summary on Remote Sensing Techniques for Identifying Dangerous Glacial Lakes}

Inventories, monitoring and evaluation of glacial lakes can be done with the help of satellite images precisely integrated with a geographical information system (GIS) (Bajracharya et al.2002). Multi-spectral satellite imagery is useful in determining the extent of glacial lakes using NDWI or by manual delineation (Zhang et al. 2015; Nie et al. 2017). This technique has made easier for monitoring lake area changes from past to present and identifying rapidly expanding glacial lakes in the remote and fragile Himalayas.

Several studies have been conducted to identify PDGL by developing various approaches, hazard assessment and GLOF susceptibility assessment techniques using satellite images and digital elevation model (DEM) (ICIMOD 2011; Wang et al. 2011, 2012; Aggarwal et al. 2017; Prakash and Nagarajan 2017; Rounce et al. 2017b). Wang et al. (2011) selected five parameters, i.e., mother glacier area, distance between lake and glacier terminus, slope between lake and glacier, mean slope of moraine dam, and mother glacier snout steepness, to identify the first order dangerous glacial lakes in southeastern Tibetan Plateau using Landsat images, ALOS AVNIR-2 and DEM. The recent study have found strong melting and deformation of southeastern Tibetan glaciers using satellite data (Du et al. 2019). Wang et al. (2012) used five indices (dam type, size of lake, changes in area, dam characteristics and distance between lake and parent glacier) to identify PDGL in the Chinese Himalaya using ASTER images and digitized DEM from topographic maps. Rounce et al. (2017b) evaluated the hazards of the Nepalese glacial lakes by modelling ice avalanche trajectories, landslides/rockfalls, upstream GLOFs, and moraine stability using Randolph Glacier Inventory and geo-morphometric analysis of $30 \mathrm{~m}$ ASTER GDEM. Out of 41 GLOF events from moraine dammed lakes in Himalaya, $50 \%$ were triggered by ice avalanche and $75 \%$ occurred in monsoon season. Hence, an outburst susceptibility assessment method was developed to identify dangerous lakes using analytical hierarchy process, remote sensing and GIS tools, considering 11 factors including mass movements, seismic and climatic conditions (Prakash and Nagarajan 2017).

Remote sensing techniques and approaches are useful to identify first order dangerous glacial lakes, however these techniques have their own limitations to find the stability of a glacial lake. For example, remote sensing cannot provide information regarding seepages through moraine, sub- or en-glacial pathways of flood (Rounce et al. 2017a). Seepage water in the moraine weakens the dam that might lead to uncertain GLOF (Lamsal et al. 2016). Many studies suggest that use of high resolution DEM data is necessary to accurately reveal the geomorphological characteristics of lake and surroundings. Hence, sole reliance on remote sensing data is also inadequate for finding the degree of a glacial lake's instability (ICIMOD 2011). Adequate field data and verification, use of high resolution data, update on current knowledge on GLOF triggering mechanism and modellings are challenging, however this will help in improving remote sensing approaches to identify and prioritize dangerous glacial lakes.

\section{RESULTS}

\subsection{Evolution and Status of Typical Glacial Lakes}

\subsubsection{The Case Studies of Imja Tsho, Tsho Rolpa, and Thulagi}

Imja Tsho is formed at the lower tip of its mother glaciers (Imja-Lhotse Shar glaciers) and drains through a dam formed by the end moraine giving rise to the Imja Khola, a tributary of Dudh Koshi (ICIMOD 2011; Chen et al. 2014). The history of the development of the Imja Tsho started with small ephemeral ponds in the late 1950s (Watanabe et al. 1994) and Bajracharya et al. (2007) calculated the area of lake in 1962 as $0.028 \mathrm{~km}^{2}$. Imja Tsho expanded to 0.64 $\mathrm{km}^{2}$ in 1987 , rapidly increasing to $0.69,0.9$, and $1.34 \mathrm{~km}^{2}$ in 1996, 2006, and 2016 respectively. During period of 1987 2016, Imja Tsho expanded by $0.024 \mathrm{~km}^{2} \mathrm{yr}^{-1}$ (Fig. 2, Table 1). The bathymetric survey conducted in 1992 (Yamada and Sharma 1993), 2002 (Sakai et al. 2003), and 2012 (SomosValenzuela et al.2014), reveals that the volume of Imja Tsho have expanded by $\sim 140 \%$ in two decades between 1992 and 2012 (Table 2). A study in 2014 revels the maximum depth of lake is $150 \mathrm{~m}$ with 78.4 million $\mathrm{m}^{3}$ volume of water (Haritashya et al. 2018). The maximum potential flood volume calculated for Imja Tsho in SLA (Steep Lake Front Area) of angle $5.4^{\circ}$ is 0.4 million $\mathrm{m}^{3}$ in 2015 (Rounce et al. 2017b).

Tsho Rolpa glacial lake is fed by the Trakarding glacier (Reynolds 1999; Rana et al. 2000; Benn et al. 2007; 
ICIMOD 2011). The development of Tsho Rolpa started with the coalescence of six small supraglacial ponds in the late 1950s, after which the lake grew in a linear trend (Shrestha et al. 2011). The lake area was $0.23 \mathrm{~km}^{2}$ in 1958 (ICIMOD 2011); it subsequently grew to $1.4 \mathrm{~km}^{2}$ in 1987 and $1.52 \mathrm{~km}^{2}$ in 1996. In 1993, the volume of lake was $0.0766 \mathrm{~km}^{3}$ (WECS 1994). Chikita et al. (1998) found that the Tsho Rolpa expansion was due to bottom subsidence causing ice melt below the lake bottom and the horizontal retreat of glacier terminus. In 2000, the lake area decreased to $1.53 \mathrm{~km}^{2}$ (ICIMOD 2011) because of engineering work to lower the level of the lake by draining the lake-water through an outlet channel in 1999 (Reynolds 1999). Rounce et al. (2017b) estimated 66.3 million $\mathrm{m}^{3}$ maximum potential flood volume at $17.4^{\circ}$ SLA in 2015 . The Tsho Rolpa had been progressively deepening since its formation with an average deepening rate during 24 years of 1970 - 1994 considered to be $>5 \mathrm{my}^{-1}$ (Sakai et al. 2000). Sakai et al. (2000) evaluated the deepening rate as $1.2 \mathrm{my}^{-1}$ in 1994 ; however, the average lake deepening rate calculated in 2009 was $0.43 \mathrm{my}^{-1}$ (ICIMOD 2011). The Trakarding glacier provided melt water as well as the addition space for horizontal lake expansion (Chikita et al. 1998). Thus, Tsho Rolpa was growing both vertically and horizontally. However, the lake

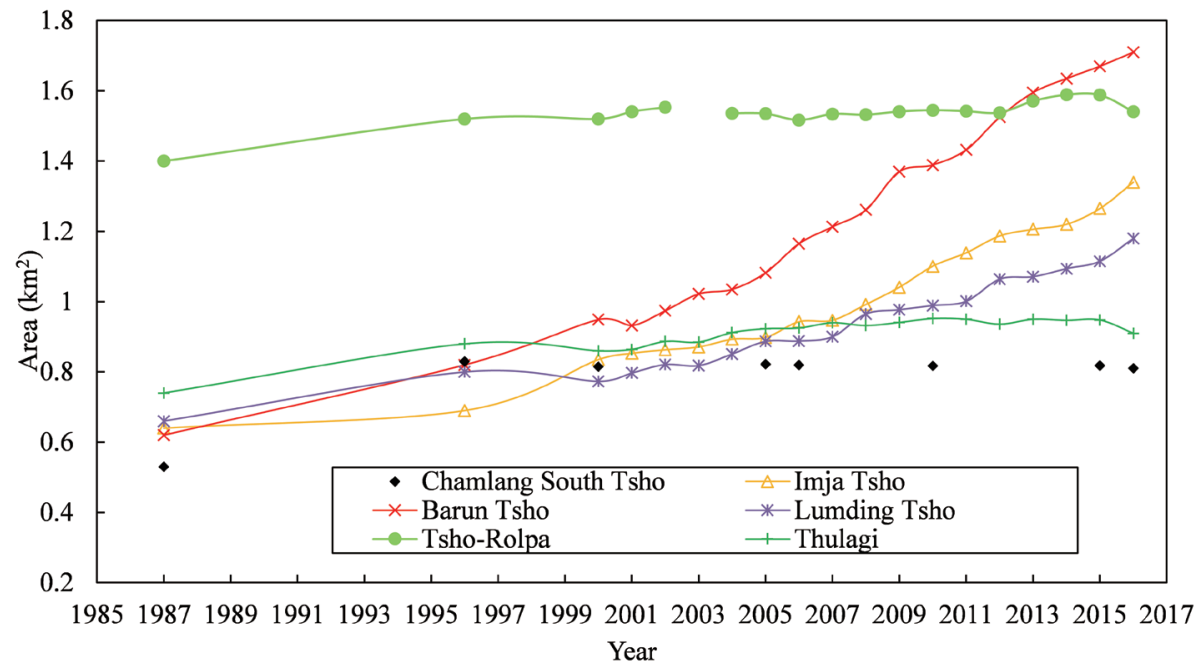

Fig. 2. Development of typical glacial lakes between 1987 and 2016 in the Nepalese Himalaya (after Rounce et al. 2016).

Table 1. Status of potentially dangerous glacial lakes.

\begin{tabular}{c|c|cc|c}
\hline \multirow{2}{*}{ Lake } & \multirow{2}{*}{ Elevation (m) } & \multicolumn{2}{|c|}{ Decadal expansion rate } & \multirow{2}{*}{ Overall Risk (Rounce et al. 2016) } \\
\cline { 3 - 4 } & & $\mathbf{1 9 8 7} \mathbf{- 2 0 1 6}\left(\mathbf{k m}^{\mathbf{2}} \mathbf{~ y r}^{-\mathbf{1}}\right)$ & $\mathbf{2 0 0 6} \mathbf{- 2 0 1 6}(\boldsymbol{\%})$ & Moderate \\
\hline Imja Tsho & 5003 & 0.024 & 42.1 & High \\
Tsho Rolpa & 4550 & 0.005 & 1.6 & High \\
Thulagi & 4003 & 0.006 & -1.6 & Very High \\
Barun Tsho & 4530 & 0.038 & 46.8 & High \\
Lumding Tsho & 4831 & 0.018 & 32.9 & High \\
Chamlang Tsho & 4924 & 0.010 & -1.2 & \\
\hline
\end{tabular}

Table 2. Comparison of bathymetric studies of Imja Tsho in various years.

\begin{tabular}{c|ccccc}
\hline Parameter & $\mathbf{1 9 9 2}^{*}$ & $\mathbf{2 0 0 2}$ & $\mathbf{2 0 1 2}$ & $\mathbf{2 0 1 4}$ & Expansion rate $\left(\mathbf{1 9 9 2} \mathbf{- 2 0 1 4}, \mathbf{y r}^{\mathbf{1}}\right)$ \\
\hline Volume $\left(\times 10^{6} \mathrm{~m}^{3}\right)$ & 28 & 35.8 & $67.1 \pm 3.7$ & 78.4 & 0.026 \\
Maximum depth $(\mathrm{m})$ & 98.5 & 90.5 & $116.3 \pm 5.2$ & 150 & 2.34 \\
Average depth $(\mathrm{m})$ & 47 & 41.6 & $48 \pm 2.9$ & - & \\
\hline
\end{tabular}

Note: *1992 (Yamada and Sharma 1993); 2002 (Sakai et al. 2003); 2012 (Somos-Valenzuela et al. 2014); 2014 (Haritashya et al. 2018). 
area has been stable since the mitigation works employed in 1999. This study found the $1.54 \pm 0.12 \mathrm{~km}^{2}$ area of Tsho Rolpa in 2016 with an expansion rate of $0.005 \mathrm{~km}^{2} \mathrm{yr}^{-1}$ in period of 1987 - 2016.

The Thulagi lake development took place by coalescence and enlargement of small supraglacial ponds over 50 to 60 years. In 1995, Thulagi Lake had an area and length of $0.76 \mathrm{~km}^{2}$ and $1.97 \mathrm{~km}$, respectively, which by $2009 \mathrm{had}$ expanded to $0.94 \mathrm{~km}^{2}$ in area and $2.54 \mathrm{~km}$ in length (WECS 1995; ICIMOD 2011). The volume of the lake increased from 31.8 - 35.3 million $\mathrm{m}^{3}$ by 2009 (WECS 1995; ICIMOD 2011). The area of Thulagi is pretty stable after 2004 (Fig. 2) and this study found $0.91 \pm 0.87 \mathrm{~km}^{2}$ area in 2016 . A recent bathymetric measurement in 2017 shows maximum depth of lake is $76 \mathrm{~m}$ with 36.1 million $\mathrm{m}^{3}$ water storage (Haritashya et al. 2018).

\subsubsection{The Case Studies of Chamlang Tsho, Lumding Tsho, and Barun Tsho}

Despite Chamlang Tsho, Lumding Tsho, and Barun Tsho glacial lakes being listed as potentially dangerous glacial lakes, these glacial lakes are less studied as compared to glacial lakes aforementioned. The decadal evolution of these three glacial lakes from $1987-2016$ are shown in Fig. 3. The Chamlang South Tsho started to evolve from

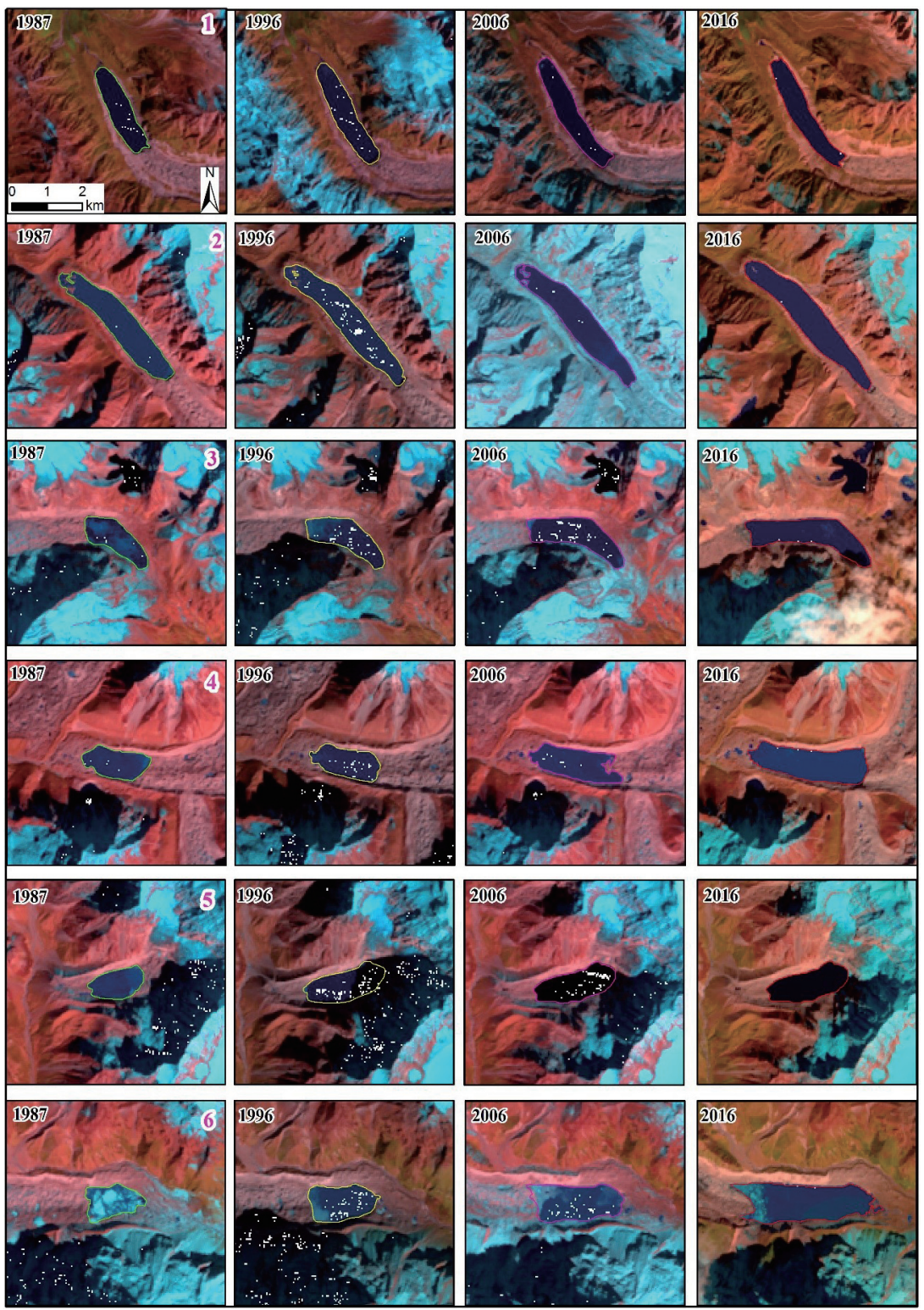

Fig. 3. Decadal evolution map of six typical glacial lakes from 1987 to 2016 at scale size of 1:100000. The number indicates respective glacial lakes as shown in Fig. 1 as 1 = Thulagi (Dona); 2 = Tsho Rolpa; 3 = Lumding Tsho; 4 = Imja Tsho; 5 = Chamlang South Tsho; 6 = Barun Tsho (Lower). 
small lakes probably during the early 1960s (Sawagaki et al. 2012); it reached $0.04 \mathrm{~km}^{2}$ in 1964 (Lamsal et al. 2016) and then grew consistently reaching to $0.83 \mathrm{~km}^{2}$ in 1996 . Since then the lake area has been quite stable (Fig. 2). The depth and volume of this lake were estimated to be $87 \mathrm{~m}$ and $35.6 \times 10^{6} \mathrm{~m}^{3}$, respectively by bathymetric measurement in 2009 (Sawagaki et al. 2012).

The evolution of Lumding Tsho and Barun Tsho (Fig. 3) reveals that they have been increasing in area. Bathymetric study of Lumding Tsho in 2015 revealed the volume of that lake to be $57.7 \times 10^{6} \mathrm{~m}^{3}$ with an average depth of $51 \mathrm{~m}$ and a maximum depth of $114 \mathrm{~m}$ (Rounce et al. 2016). Based on remote sensing analysis, Rounce et al. (2016) rated Lumding Tsho as a high risk lake susceptible to both dynamic and self-destructive failure and Lower Barun Tsho as very high risk lake susceptible to dynamic failure. The area of Lumding Tsho was $0.104 \mathrm{~km}^{2}$ area in 1963 (Shrestha and Balla 2011). This study finds $0.66 \pm 0.05 \mathrm{~km}^{2}$ area of Lumding Tsho in 1987 growing to $0.8 \pm 0.07 \mathrm{~km}^{2}$ in 1996 and reaching to $1.18 \pm 0.09 \mathrm{~km}^{2}$ in 2016 . The growth rate of Lumding Tsho was $0.018 \mathrm{~km}^{2} \mathrm{y}^{-1}$ for the period of 1987 - 2016 (Table 1). Bathymetric measurement of Barun Tsho was conducted for the first time in 2015, which revealed the maximum depth of lake is $205 \mathrm{~m}$ with $\sim 112.3$ million $\mathrm{m}^{3}$ water storage (Haritashya et al. 2018). Barun Tsho had an area of $0.62 \mathrm{~km}^{2}$ in 1987, significantly growing at the rate of $0.038 \mathrm{~km}^{2} \mathrm{yr}^{-1}$ attending the size of $1.71 \pm 0.1 \mathrm{~km}^{2}$ in 2016 .

\subsection{Comparison Between Evolutions of Different Typical Lakes and Their Characteristics}

The six typical PDGL in the Nepalese Himalaya possess interesting characteristics in the historical process of their evolutions. All six lakes started to evolve from the coalescence of supraglacial lakes or ponds at the tip of their parent glaciers. All lakes gradually started to expand after the second half of $20^{\text {th }}$ century, however their expansion rates varied with time. For example, Imja Tsho, Barun Tsho, and Lumding Tsho show significant expansion of $42.1,46.8$, and $32.9 \%$ respectively, in the recent period of 2006 - 2016, however the area of Tsho Rolpa, Thulagi, and Chamlang Tsho are quite stable in recent years (Fig. 3). Most of the attention and research have been focused in Imja Tsho, however from the late 1980s, Barun Tsho have expanded more rapidly (Fig. 2). Bathymetric study also revealed that the depth and volume of Barun Tsho are $~ 37$ and $~ 27 \%$ greater than Imja Tsho, as mentioned in section 3.1. Continue expansion (area and deepening) of glacial lakes also leads to the expansion of its volume and thus increase in potential flood volume. Formally, Tsho Rolpa was the biggest potentially dangerous glacial lake of Nepal, however this study show Barun Tsho has exceeded Tsho Rolpa in its area by $\sim 10 \%$ in 2016 (Fig 2). Mapping six glacial lakes (Fig. 3) reveal that increase in areal extent of these glacial lakes are due to hori- zontal retreat of glacier terminus and enhanced calving, as also reported by previous studies (Sakai et al. 2003). The width and depth of glacial lake at calving front (glacier and lake interface) determine the expansion of glacial lake. Barun Tsho have the highest lake width $(770 \mathrm{~m})$ at calving front than other glacial lakes, resulting in its high expansion (Haritashya et al. 2018). Hence, the different geometry of glacial lakes is one of the reason for difference in growth rates of these six glacial lakes. Transmission of thermal energy from fetch of glacial lakes connected to glaciers causes submerged ice melt resulting calving of glacier terminus, which in return provides melt water in triggering lake expansion, as reported in Tsho Rolpa (Chikita et al. 1997).

\section{DISCUSSION}

After the devastating earthquake in 2015, DHM, Nepal announced that the existing six PDGL at high risk of burst (Acharya 2016). As a result, in 2016, and with the support of international aid (UNDP 2013), DHM worked with the Nepalese Army to make an outlet and drain more than 4 million $\mathrm{m}^{3}$ of water from Imja Tsho, lowering the lake by more than $3.5 \mathrm{~m}$. The objective was to prevent a possible GLOF event (Khadka 2016). However, a GLOF modelling study suggests that Imja Tsho must be lowered by at least $10 \mathrm{~m}$ from its original height $(5010 \mathrm{~m})$ to prevent major damage and $20 \mathrm{~m}$ to completely eliminate the chance of a downstream GLOF (Somos-Valenzuela et al. 2015). Decision making analysis also suggests that lowering the lake 10 or $20 \mathrm{~m}$ is an effective response for Imja Tsho's risk management, as the time and occurrence of a GLOF is uncertain (Cuellar and McKinney 2017). Tsho Rolpa's area is quite stable after mitigation work adopted in 2000. Seepage and overtopping waves caused by hanging glaciers falling into the lake are possible hazards that can breach moraine dam of Tsho-Rolpa (Shrestha et al. 2011). Modelling Tsho Rolpa shows that dam failure due to water overtopping could cause of 33215 and $35594 \mathrm{~m}^{3} \mathrm{~s}^{-1}$ peak discharge at the lake outlet for 20 and $30 \mathrm{~m}$ breach depths, respectively. While, failure due to seepage shows peak discharges of 21551 and 34234 $\mathrm{m}^{3} \mathrm{~s}^{-1}$ for the same breach depths (Shrestha and Nakagawa 2014). Fujita et al. (2013) remarked that glacial lakes with wide damming moraines are unlikely to cause GLOFs, so, it can be said that there is no immediate danger from the Imja Tsho since its damming moraine is wide $(>500 \mathrm{~m})$. Budhathoki et al. (2010) used the empirical scoring system and assessed that GLOF risk from an outburst from Imja Tsho is Moderate; signifying GLOF could occur at any time. Thulagi lake is rated as a high risk lake (Table 1), however this lake is relatively stable because of reduced geomorphological process rate and downwasting of dam due to vegetated surface (Haritashya et al. 2018). Chamlang South was estimated to have little capacity for future expansion due to its confinement by rock and lateral moraine, however, this 
lake has a high possibility of bursting because of seepage and hanging glaciers that could trigger a GLOF in future (Lamsal et al. 2016).

Overall, we discussed the literatures, methodological used, reports and the findings related with potential dangerous glacial lakes and risk of outburst floods. Additionally, the added value of our study is evolution and decadal expansion of six glacial lakes observed using Landsat images from 1987 to latest time scale in Nepal Himalaya. Evaluating the risks of all typical glacial lakes, Barun Tsho has the greatest area expansion in recent years (Fig. 2), in spite the lake is not given much attention. The upstream GLOF can trigger a vigorous GLOF from lower situated Barun Tsho by destabilizing the lake. It has been found by remote sensing that this lake is susceptible to dynamic failure and that would have high downstream impact (Rounce et al. 2016). Lumding Tsho has not been studied in detail despite of its expansion. In the course of this glacial lake expansion, hanging glaciers located behind the calving front and upstream small lakes are potential hazards that could trigger GLOF from Lumding Tsho (Rounce et al. 2016). Thus, Barun Tsho and Lumding Tsho should be prioritized in the adoption of appropriate mitigation measures.

A remote survey by satellite images of earthquake damage to 491 glacial lakes did not find any evidence of burst from these glacial lakes (Kargel et al. 2015). No any severe GLOFs are reported in the Nepalese Himalaya after the 2015 earthquake, except one GLOF from a supraglacial pond observed in June 2016 from the Lhotse glacier in the Everest region (Rounce et al. 2017a). This shows that the glacial lakes in the Nepalese Himalaya are in a stable condition at present. However, we cannot predict when they will fail. The stability of dam of glacial lakes depends upon its geometry, internal structure and material properties. The triggering mechanisms like ice, snow and rock avalanching, glacier calving, wave overtopping, atmospheric triggers, ice-cored moraine degradation and earthquake are cause of dam failure and GLOFs (Westoby et al. 2014). The effect of climate change on the glacial lakes is rather complex, but clearly the ongoing temperature rise (IPCC 2014) has an indirect effect on glacial lakes, as it increases the glacier melt and retreat of glaciers. The increase in lake expansion rate in recent decades not only threatens downstream communities but also indicates the significant retreat of glaciers. The significant retreat of glaciers (Table 3) explains the increase in area of respective glacial lakes.

\section{CONCLUSION}

Imja Tsho, Barun Tsho, and Lumding Tsho have expanded rapidly in the recent decade of 2006 - 2016, by 42.1, 46.8 , and $32.9 \%$ respectively, while Tsho-Rolpa, Thulagi, and Chamlang South Tsho are pretty stable. At present, these glacial lakes are quite stable in term of burst risk, however several GLOF triggering factors make them at risk of burst anytime in future. Despite of high expansion of Barun Tsho and Lumding Tsho, GLOF's has not risen to date. Risk can be reduced as like as the cases of Tsho-Rolpa (in 2000) and Imja (in 2016) where water levels have been lowered by the action of Nepal Government. Detail studies are needed for Barun Tsho and Lumding Tsho which requires a combination of remote sensing and in-situ observations of the geology and geophysical conditions. Continuous model-based monitoring and risk assessment, mitigation measures and disaster management strategies are necessary for reducing the likely impact of GLOFs.

Acknowledgements This study was supported by grants from the Natural Science foundation of China (41571068, 21661132003). The authors are very grateful to Mr. Binod Baniya and colleagues for their assistances and valuable advices.

\section{REFERENCES}

Acharya, S., 2016: Six glacial lakes in high risk of outburst. My República, Nepal Republic Media Pvt. Ltd., Kathmandu. Available at http://www.myrepublica.com/ news/2883/.

Aggarwal, S., S. C. Rai, P. K. Thakur, and A. Emmer, 2017: Inventory and recently increasing GLOF susceptibility of glacial lakes in Sikkim, Eastern Himalaya. Geomorphology, 295, 39-54, doi: 10.1016/j.geomorph.2017.06.014. [Link]

Bajracharya, S. R. and P. Mool, 2009: Glaciers, glacial lakes and glacial lake outburst floods in the Mount Everest region, Nepal. Ann. Glaciol., 50, 81-86, doi: 10.3189/172756410790595895. [Link]

Table 3. Retreat of different glacier termini associated with glacial lakes.

\begin{tabular}{ccccc}
\hline Glacial lake & Mother glacier & Study period & Retreat $\left(\mathbf{m y}^{-1}\right)$ & Reference \\
\hline Imja Tsho & Imja-Lhotse Shar glaciers & $1992-2012$ & 43 & Somos-Valenzuela et al. 2014 \\
Tsho-Rolpa & Trakarding glacier & $1960-2009$ & $\sim 72$ & ICIMOD 2011 \\
Thulagi & Thulagi glacier & $1990-2009$ & 35 & ICIMOD 2011 \\
Lumding Tsho & Lumding glacier & $1976-2007$ & $\sim 47$ & Bajracharya and Mool 2009 \\
\hline
\end{tabular}


Bajracharya, S. R., P. K. Mool, and S. P. JoshiI, 2002: Spatial database development of glaciers and glacial lakes in the identification potentially dangerous glacial lakes of Nepal using remote sensing and geographic information systems. Asian Conference on Remote Sensing. Available at http://a-a-r-s.org/aars/proceeding/ ACRS2002/Papers/MEM02-1.pdf.

Bajracharya, S. R., P. K. Mool, and B. R. Shrestha, 2007: Impact of Climate Change on Himalayan Glaciers and Glacial Lakes: Case Studies on GLOF and Associated Hazards in Nepal and Bhutan, International Centre for Integrated Mountain Development (ICIMOD), Kathmandu, Nepal, $133 \mathrm{pp}$.

Benn, D. I., C. R. Warren, and R. H. Mottram, 2007: Calving processes and the dynamics of calving glaciers. Earth-Sci. Rev., 82, 143-179, doi: 10.1016/j. earscirev.2007.02.002. [Link]

Bolch, T., M. Buchroithner, T. Pieczonka, and A. Kunert, 2008: Planimetric and volumetric glacier changes in the Khumbu Himal, Nepal, since 1962 using Corona, Landsat TM and ASTER data. J. Glaciol., 54, 592-600, doi: 10.3189/002214308786570782. [Link]

Bolch, T., A. Kulkarni, A. Kääb, C. Huggel, F. Paul, J. G. Cogley, H. Frey, J. S. Kargel, K. Fujita, M. Scheel, S. Bajracharya, M. Stoffel, 2012: The state and fate of Himalayan glaciers. Science, 336, 310-314, doi: 10.1126/ science.1215828. [Link]

Budhathoki, K. P., O. Bajracharya, and B. Pokharel, 2010: Assessment of Imja Glacier Lake outburst flood (GLOF) risk in Dudh Koshi River Basin using remote sensing techniques. J. Hydrol.Meteorol., 7, 75-91, doi: 10.3126/jhm.v7i1.5618. [Link]

Byers III, A. C., E. A. Byers, D. C. McKinney, and D. R. Rounce, 2017: A field-based study of impacts of the 2015 earthquake on potentially dangerous Glacial Lakes in Nepal. HIMALAYA, the Journal of the Association for Nepal and Himalayan Studies, 37, 26-37.

CBS, 2012: National Population and Housing Census 2011 (National Report), Government of Nepal, National Planning Commission Secretariat, Central Bureau of Statistics, Kathmandu, Nepal.

Chen, W., T. Doko, C. Liu, T. Ichinose, H. Fukui, Q. Feng, and P. Gou, 2014: Changes in Rongbuk lake and Imja lake in the Everest region of Himalaya. Int. Arch. Photogramm. Remote Sens. Spatial Inf. Sci., XL-2, 259-266, doi: 10.5194/isprsarchives-XL-2-259-2014. [Link]

Chikita, K., T. Yamada, A. Saka, and P. P. Ghimire, 1997: Hydrodynamic effects on the basin expansion of Tsho Rolpa Glacier Lake in the Nepal Himalaya. Bulletin of Glacier Research, 15, 59-69.

Chikita, K., J. Jha, and T. Yamada, 1998: The basin expansion mechanism of a supraglacial lake in the Nepal Himalaya. Journal of the Faculty of Science, Hokkaido
University, 11, 501-521.

Cuellar, A. D. and D.C. McKinney, 2017: Decision-Making Methodology for Risk Management Applied to Imja Lake in Nepal. Water, 9, 591, doi: 10.3390/w9080591. [Link]

Du, W., X. Liu, J. Guo, Y. Shen, W. Li, and X. Chang, 2019: Analysis of the melting glaciers in Southeast Tibet by ALOS-PALSAR data. Terr. Atmos. Ocean. Sci., 30, 7-19, doi: 10.3319/TAO.2018.07.09.03. [Link]

Fujita, K., A. Sakai, S. Takenaka, T. Nuimura, A. B. Surazakov, T. Sawagaki, and T. Yamanokuchi, 2013: Potential flood volume of Himalayan glacial lakes. Nat. Hazards Earth Syst. Sci., 13, 1827-1839, doi: 10.5194/ nhess-13-1827-2013. [Link]

Goda, K., T. Kiyota, R. M. Pokhrel, G. Chiaro, T. Katagiri, K. Sharma, and S. Wilkinson, 2015: The 2015 Gorkha Nepal earthquake: Insights from earthquake damage survey. Front. Built Environ., 1, doi: 10.3389/ fbuil.2015.00008. [Link]

Haritashya, U. K., J. S. Kargel, D. H. Shugar, G. J. Leonard, K. Strattman, C. S. Watson, D. Shean, S. Harrison, K. T. Mandli, and D. Regmi, 2018: Evolution and Controls of Large Glacial Lakes in the Nepal Himalaya. Remote Sens., 10, doi: 10.3390/rs10050798. [Link]

ICIMOD, 2011: Glacial Lakes and Glacial Lake Outburst Floods in Nepal, ICIMOD, Kathmandu, 99 pp.

IPCC, 2014: Climate Change 2014: Synthesis Report. Contribution of Working Groups I, II and III to the Fifth Assessment Report of the Intergovernmental Panel on Climate Change, IPCC, Geneva, Switzerland, $151 \mathrm{pp.}$

Ives, J. D., R. B. Shrestha, and P. K. Mool, 2010: Formation of Glacial Lakes in the Hindu Kush-Himalayas and GLOF Risk Assessment, ICIMOD, Kathmandu, $56 \mathrm{pp}$.

Kargel, J. S., G. J. Leonard, D. H. Shugar, U. K. Haritashya, A. Bevington, E. J. Fielding, K. Fujita, M. Geertsema, E. S. Miles, J. Steiner, E. Anderson, S. Bajracharya, G. W. Bawden, D. F. Breashears, A. Byers, B. Collins, M. R. Dhital, A. Donnellan, T. L. Evans, M. L. Geai, M. T. Glasscoe, D. Green, D. R. Gurung, R. Heijenk, A. Hilborn, K. Hudnut, C. Huyck, W. W. Immerzeel, Jiang Liming, R. Jibson, A. Kääb, N. R. Khanal, D. Kirschbaum, P. D. A. Kraaijenbrink, D. Lamsal, Liu Shiyin, Lv Mingyang, D. McKinney, N. K. Nahirnick, Nan Zhuotong, S. Ojha, J. Olsenholler, T. H. Painter, M. Pleasants, Pratima KC, QI Yuan, B. H. Raup, D. Regmi, D. R. Rounce, A. Sakai, Shangguan Donghui, J. M. Shea, A. B. Shrestha, A. Shukla, D. Stumm, M. van der Kooij, K. Voss, Wang Xin, B. Weihs, D. Wolfe, Wu Lizong, Yao Xiaojun, M. R. Yoder, N. Young, 2015: Geomorphic and geologic controls of geohazards induced by Nepal's 2015 Gorkha earthquake. Science, 351, aac8353, doi: 10.1126/science.aac8353. [Link]

Khadka, N. S., 2016: Nepal drains dangerous Everest Lake. 
BBC World Service. Available at http://www.bbc. com/news/world-asia-37797559.

Khadka, N., G. Zhang, and S. Thakuri, 2018: Glacial Lakes in the Nepal Himalaya: Inventory and Decadal Dynamics (1977-2017). Remote Sens., 10, 1913, doi: 10.3390/ rs10121913. [Link]

Lamsal, D., T. Sawagaki, T. Watanabe, and A. C. Byers, 2016: Assessment of glacial lake development and prospects of outburst susceptibility: Chamlang South Glacier, eastern Nepal Himalaya. Geomatics, Natural Hazards and Risk, 7, 403-423, doi: 10.1080/19475705.2014.931306. [Link]

Le Fort, P., 1975: Himalayas: The collided range. Present knowledge of the continental arc. Am. J. Sci., 275-A, $1-44$.

Lutz, A., W. W. Immerzeel, S. R. Bajracharya, M. Litt, and A. Shrestha, 2016: Impacts of Climate Change on the Cryosphere, Hydrological Regimes and Glacial Lakes of the Hindu Kush Himalayas: A Review of Current Knowledge, ICIMOD Research Report, 72 pp.

McFeeters, S. K., 1996: The use of the Normalized Difference Water Index (NDWI) in the delineation of open water features. Int. J. Remote Sens., 17, 1425-1432, doi: 10.1080/01431169608948714. [Link]

Mool, P. K., D. Wangda, S. R. Bajracharya, S. P. Joshi, K. Kunzang, and D. R. Gurung, 2001: Inventory of Glaciers, Glacial Lakes and Glacial Lake Outburst Floods: Monitoring and Early Warning Systems in the Hindu Kush-Himalayan Region - Bhutan, ICIMOD, Nepal.

Nie, Y., Y. Sheng, Q. Liu, L. Liu, S. Liu, Y. Zhang, and C. Song, 2017: A regional-scale assessment of Himalayan glacial lake changes using satellite observations from 1990 to 2015. Remote Sens. Environ., 189, 1-13, doi: 10.1016/j.rse.2016.11.008. [Link]

Prakash, C. and R. Nagarajan, 2017: Outburst susceptibility assessment of moraine-dammed lakes in Western Himalaya using an analytic hierarchy process. Earth Surf. Process. Landf., 42, 2306-2321, doi: 10.1002/ esp.4185. [Link]

Rana, B., A. B. Shrestha, J. M. Reynolds, and R. Aryal, 2000: Hazard assessment of the Tsho Rolpa Glacier Lake and ongoing. Journal of Nepal Geological Society, 22, 563-570.

Reynolds, J. M., 1999: Glacial hazard assessment at Tsho Rolpa, Rolwaling, Central Nepal. Q. J. Eng. Geol. Hydrogeol., 32, 209-214, doi: 10.1144/gsl.qjeg.1999.032. p3.01. [Link]

Richardson, S. D. and J. M. Reynolds, 2000: An overview of glacial hazards in the Himalayas. Quat. Int., 65-66, 31-47, doi: 10.1016/s1040-6182(99)00035-x. [Link]

Rounce, D. R., D. C. McKinney, J. M. Lala, A. C. Byers, and C. S. Watson, 2016: A new remote hazard and risk assessment framework for glacial lakes in the Nepal Himalaya. Hydrol. Earth Syst. Sci., 20, 3455-3475, doi: 10.5194/hess-20-3455-2016. [Link]

Rounce, D. R., A. C. Byers, E. A. Byers, and D. C. McKinney, 2017a: Brief communication: Observations of a glacier outburst flood from Lhotse Glacier, Everest area, Nepal. The Cryosphere, 11, 443-449, doi: 10.5194/tc-11-443-2017. [Link]

Rounce, D. R., C. S. Watson, and D. C. McKinney, 2017b: Identification of hazard and risk for glacial lakes in the Nepal Himalaya using satellite imagery from 20002015. Remote Sens., 9, 654, doi: 10.3390/rs9070654. [Link]

Sakai, A., K. Chikita, and T. Yamada, 2000: Expansion of a moraine-dammed glacial lake, Tsho Rolpa, in Rolwaling Himal, Nepal Himalaya. Limnol. Oceanogr., 45, 1401-1408, doi: 10.4319/lo.2000.45.6.1401. [Link]

Sakai, A., K. Fujita, and T. Yamada, 2003: Volume change of Imja Glacial Lake in the Nepal Himalayas. International Symposium on Disaster Mitigation \& Basin Wide Water Management, 556-561.

Sawagaki, T., D. Lamsal, A. C. Byers, and T. Watanabe, 2012: Changes in surface morphology and glacial lake development of Chamlang South Glacier in the Eastern Nepal Himalaya since 1964. Global Environmental Research, 16, 83-94.

Shrestha, A. B. and R. Aryal, 2011: Climate change in Nepal and its impact on Himalayan glaciers. Reg. Environ. Change, 11, 65-77, doi: 10.1007/s10113-010-0174-9. [Link]

Shrestha, A. B., C. P. Wake, P. A. Mayewski, and J.E. Dibb, 1999: Maximum temperature trends in the Himalaya and its vicinity: An analysis based on temperature records from Nepal for the period 1971-94. J. Climate, 12, 2775-2786, doi: 10.1175/1520-0442(1999)012<27 75:MTTITH>2.0.CO;2. [Link]

Shrestha, B. B. and H. Nakagawa, 2014: Assessment of potential outburst floods from the Tsho Rolpa glacial lake in Nepal. Nat. Hazards, 71, 913-936, doi: 10.1007/ s11069-013-0940-3. [Link]

Shrestha, B. B., H. Nakagawa, K. Kawaike, Y. Baba, and H. Zhang, 2011: Assessment of Glacial Hazards in Rolwaling Valley of Nepal and Numerical Approach to Predict Glacial Lake Outburst Flood. Annuals of Disas. Prev. Res. Inst., Kyoto Univ., No. 54B, 565-591.

Shrestha, D. P. and J. A. Zinck, 2001: Land use classification in mountainous areas: Integration of image processing, digital elevation data and field knowledge (application to Nepal). Int. J. Appl. Earth Observation Geoinformation, 3, 78-85, doi: 10.1016/s0303-2434(01)85024-8. [Link]

Shrestha, N. M. and M. K. Balla, 2011: Temporal change detection of Lumding Tsho glacial lake in Dudh-Koshi basin, Nepal. J. Environ. Res. Dev., 5, 795-800.

Somos-Valenzuela, M. A., D. C. McKinney, D. R. Rounce, and A. C. Byers, 2014: Changes in Imja Tsho in the 
Mount Everest region of Nepal. The Cryosphere, 8, 1661-1671, doi: 10.5194/tc-8-1661-2014. [Link]

Somos-Valenzuela, M. A., D. C. McKinney, A. C. Byers, D. R. Rounce, C. Portocarrero, and D. Lamsal, 2015: Assessing downstream flood impacts due to a potential GLOF from Imja Tsho in Nepal. Hydrol. Earth Syst. Sci., 19, 1401-1412, doi: 10.5194/hess-19-1401-2015. [Link]

Ueno, K., R. B. Kayastha, M. R. Chitrakar, O. R. Bajracharya, A. P. Pokhrel, H. Fujinami, T. Kadota, H. Iida, D. P. Manandhar, M. Hattori, T. Yasunari, and M. Nakawo, 2001: Meteorological observations during 19942000 at the automatic weather station (GEN-AWS) in Khumbu region, Nepal Himalayas. Bulletin of Glaciological Research, 18, 23-30.

UNDP, 2013: United Nations Development Programme, Community based glacier lake outburst and flood risk reduction in Nepal, Document Rep., Kathmandu.

Wang, W., T. Yao, Y. Gao, X. Yang, and D. B. Kattel, 2011: A first-order method to identify potentially dangerous glacial lakes in a region of the southeastern Tibetan Plateau. Mt.Res. Dev., 31, 122-130, doi: 10.1659/mrdjournal-d-10-00059.1. [Link]

Wang, X., S. Liu, Y. Ding, W. Guo, Z. Jiang, J. Lin, and Y. Han, 2012: An approach for estimating the breach probabilities of moraine-dammed lakes in the Chinese Himalayas using remote-sensing data. Nat. Hazards Earth Syst. Sci., 12, 3109-3122, doi: 10.5194/ nhess-12-3109-2012. [Link]

Watanabe, T., J. D. Ives, and J. E. Hammond, 1994: Rapid growth of a glacial lake in Khumbu Himal, Himalaya: Prospects for a catastrophic flood. Mt. Res. Dev., 14,
329-340, doi: 10.2307/3673729. [Link]

WECS, 1994: Report for the field investigation on the TshoRolpa Glacier, Rlwaling valley, February 1993-June 1994 Rep., WECS, Kathmandu.

WECS, 1995: Preliminary report on the Thulagi Glacier Lake, Dhana Khola, Marsyangdi Basin Rep. 2/3/170795/1/1, WECS, Kathmandu.

Westoby, M. J., N. F. Glasser, J. Brasington, M. J. Hambrey, D. J. Quincey, and J. M. Reynolds, 2014: Modelling outburst floods from moraine-dammed glacial lakes. Earth-Sci. Rev., 134, 137-159, doi: 10.1016/j. earscirev.2014.03.009. [Link]

Yamada, T. and C. K. Sharma, 1993: Glacier lakes and outburst floods in the Nepal Himalaya. Snow and Glacier Hydrology (Proceeding of the Kathmandu Symposium, Kathmandu), IAHS Publ. No. 218, 319-330.

Zhang, G., T. Yao, H. Xie, W. Wang, and W. Yang, 2015: An inventory of glacial lakes in the Third Pole region and their changes in response to global warming. Global Planet. Change, 131, 148-157, doi: 10.1016/j.gloplacha.2015.05.013. [Link]

Zhang, G., T. Yao, C. K. Shum, S. Yi, K. Yang, H. Xie, W. Feng, T. Bolch, L. Wang, A. Behrangi, H. Zhang, W. Wang, Y. Xiang, and J. Yu, 2017a: Lake volume and groundwater storage variations in Tibetan Plateau's endorheic basin. Geophys. Res. Lett., 44, 5550-5560, doi: 10.1002/2017g1073773. [Link]

Zhang, G., G. Zheng, Y. Gao, Y. Xiang, Y. Lei, and J. Li, 2017b: Automated water classification in the Tibetan plateau using Chinese GF-1 WFV data. Photogramm. Eng. Rem. Sens., 83, 509-519, doi: 10.14358/ pers.83.7.509. [Link] 